\title{
Foreign Body Infection: Role of Fibronectin as a Ligand for the Adherence of Staphylococcus aureus
}

\author{
P. Vaudaux, R. Suzuki, F. A. Waldvogel, \\ J. J. Morgenthaler, and U. E. Nydegger
}

From the Division of Infectious Diseases, Department of
Medicine, University Hospital, Geneva;
and the Blood Transfusion Service, Swiss Red Cross,

Bern, Switzerland

\begin{abstract}
Foreign bodies made of polymethylmethacrylate coverslips were implanted subcutaneously into guinea pigs, were explanted four weeks later, and were tested for in vitro adherence of Staphylococcus aureus strain Wood 46. In the presence of serum, the level of staphylococcal adherence to explanted coverslips was 20 times higher than that of adherence to unimplanted coverslips. Adherence to explanted coverslips was caused by fibronectin deposits on the foreign body surface and was inhibited in a dose-related fashion by specific antibodies to fibronectin.
\end{abstract}

Implantation of prostheses and insertion of catheters into humans are associated with an enhanced risk of bacterial infection in the immediate vicinity of the synthetic foreign material; when such infection develops it compromises the function of the prosthesis or catheter [1-4]. In animal models foreign body infections have been provoked by $10^{2} \mathrm{cfu}$ of Staphylococcus aureus, whereas even $10^{6}$ bacteria have failed to cause infection in the absence of foreign material [5-7].

Foreign body infections are not cured by antimicrobial treatments that are considered to be effective in the absence of foreign material [1-4]. This observation has led to the assumption that the synthetic material creates a microenvironment that favors bacterial multiplication and reduces accessibility to antibiotics [8]. Ultrastructural studies of the surface of pacemakers and catheters removed from humans have indeed revealed extensive growth of bacterial microcolonies embedded in a thick matrix of polysaccharides [9, 10]; this

Received for publication December 16, 1983, and in revised form May 17, 1984.

This work was presented in part at the 23 rd Interscience Conference on Antimicrobial Agents and Chemotherapy in Las Vegas, Nevada, on October 24-26, 1983.

This research was supported by grant no. 3.869-0.81 from the Swiss National Research Foundation.

We thank E. Huggler, W. Zimmerli, G. Zulian, P. Baillod, and P. Lerch for assistance in this project; J. C. Cerottini, P. H. Lambert, L. Roux, B. Hirschel, and S. Suter for criticisms and suggestions; and A. Dall'aglio for secretarial assistance.

Please address requests for reprints to Dr. P. Vaudaux, Division of Infectious Diseases, Department of Medicine, University Hospital, 1211 Geneva 4, Switzerland. matrix is probably of bacterial origin. A number of other studies have documented the immediate formation of a conditioning layer of host proteins on the surface of various synthetic materials exposed to blood proteins [11, 12]. Such protein layers are known to affect the subsequent adsorption of microorganisms on a variety of natural or artificial substrates $[13,14]$. Therefore, these protein layers may control bacterial attachment during foreign body infection.

We previously developed an experimental model of foreign body infection [15] by implanting polymethylmethacrylate (MTA, Plexiglass) "tissue cages" $s c$ into guinea pigs and then infecting the animals with $10^{3} \mathrm{cfu}$ of $S$. aureus strain Wood 46, which is devoid of protein A [16]. In the present study of bacterial adherence to MTA, we placed MTA coverslips inside tissue cages. Using an in vitro assay for the measurement of adherence of $S$. aureus strain Wood 46 to MTA coverslips, we compared the adhesive properties of explanted coverslips with those of unimplanted coverslips. We found evidence that fibronectin, which is deposited on the coverslips after their sc implantation, is a major determinant of adherence of $S$. aureus strain Wood 46.

\section{Materials and Methods}

Implantation of MTA coverslips into guinea pigs. MTA coverslips $(1 \times 1 \mathrm{~cm}$, ethanol-cleaned $)$ were inserted into rigid MTA tissue cages, which were then sterilized and implanted sc into guinea pigs [15]. After four weeks the tissue cages were explanted under anesthesia [15] and opened at both 
ends for removal of the coverslips, which were rinsed twice in PBS before being used in the adherence assay.

Assay for adherence of $S$, aureus strain Wood 46. A total of $2 \times 10^{7}$ cfu of $S$. aureus strain Wood 46 were incubated with $100 \mu \mathrm{Ci}$ of [methyl${ }^{3} \mathrm{H}$ ]thymidine in $1 \mathrm{ml}$ of Mueller-Hinton broth for $3 \mathrm{hr}$ at $37 \mathrm{C}$ and were grown to a concentration of $1-2 \times 10^{8} \mathrm{cfu} / \mathrm{ml}$. After removal of the unbound radioactivity by centrifugation, the radiolabeled strain was suspended in $1 \mathrm{ml}$ of $0.15 \mathrm{M} \mathrm{NaCl}$ (saline). Thereafter, aliquots of $S$. aureus in $1 \mathrm{ml}$ of the selected attachment medium were incubated with either unimplanted or explanted MTA coverslips at $37 \mathrm{C}$ with agitation. At the end of the attachment period, the fluids containing unbound bacteria were drained, and the coverslips were transferred into new tubes containing $1 \mathrm{ml}$ of saline. This transfer procedure minimized the carryover of fluid contaminated by unbound bacteria. After incubation for $5 \mathrm{~min}$ at $20 \mathrm{C}$, a second wash was performed with $1 \mathrm{ml}$ of fresh saline for $30 \mathrm{~min}$ at $20 \mathrm{C}$. Finally, the coverslips were transferred into new tubes containing $1 \mathrm{ml}$ of PBS and were incubated for another $30 \mathrm{~min}$ at $37^{\circ} \mathrm{C}$ with agitation. This last procedure released $<20 \%$ of the bacteria from the coverslips. Thereafter, drained slides were immersed into scintillation fluid (Dimilume ${ }^{\circledR}$; Packard Instruments, Houston), and their radioactivity was counted in a liquid scintillation counter (model no. LS-3145 T; Beckman Instruments, Fullerton, Calif). The cpm values were then multiplied by the cfu/cpm ratio of the radiolabeled culture of $S$. aureus strain Wood 46 (average ratio, 43 $\pm 14 \mathrm{cfu} / \mathrm{cpm} ; 40$ experiments). This procedure allowed the quantification of the bacteria adherent to the coverslips.

Purification of human fibronectin and fibrinogen. Fibronectin was purified from pooled human plasma by affinity chromatography on gelatin-Sepharose 4B (Pharmacia Fine Chemicals, Piscataway, NJ) [17]. Plasma proteins that bound nonspecifically to the matrix were first removed with a column packed with unmodified Sepharose [18]. Plasma proteins that were weakly bound to the gelatin-Sepharose were washed off with $1 M$ urea. Thereafter, fibronectin was eluted with $4 M$ urea, concentrated by ultrafiltration, and stored as described previously [19], Purified fibronectin was shown to be free of contaminants by SDS-PAGE [20] (figure 1). The concentration of the purified

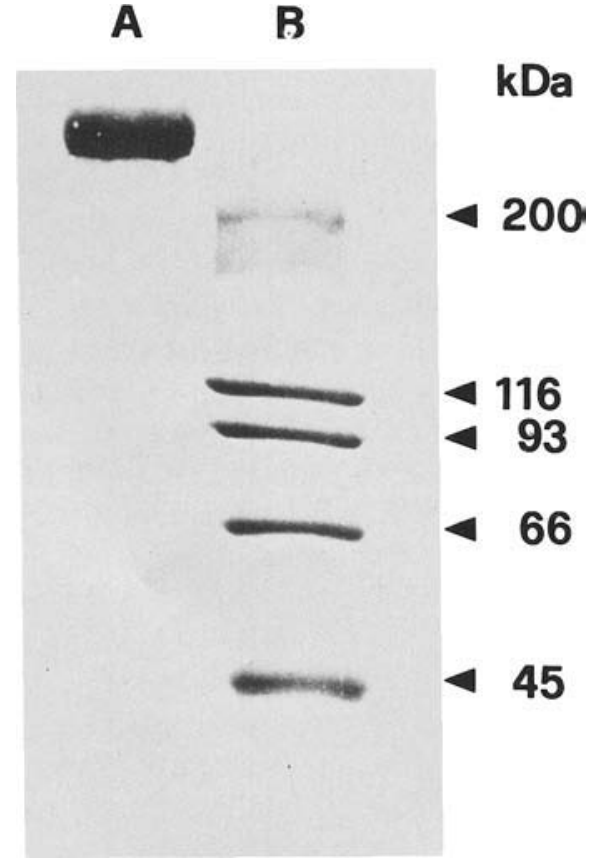

Figure 1. SDS-PAGE of purified fibronectin on a discontinuous slab gel. A gradient gel was made (5\%-15\% in acrylamide), and the samples were tested under reducing conditions. Lane A shows the results obtained with $4 \mu \mathrm{g}$ of purified human fibronectin, and lane B shows those obtained with molecular weight standard (myosin, $\beta$-galactosidase, phosphorylase $B$, bovine serum albumin, ovalbumin).

fibronectin was measured spectrophotometrically by use of an absorbance value of 1.28 at $280 \mathrm{~nm}$ [21]. Fibronectin was also measured with the fibronectin turbidimetric immunoassay from Boehringer (Mannheim, Federal Republic of Germany) and was found to be active in a macrophage phagocytic assay [22].

Fibrinogen was prepared from a cryoprecipitate of pooled human plasma, which was extracted twice with a buffer containing $10 \%$ ethanol. The unextracted material (containing fibrinogen) was then solubilized in citrate-glycine buffer and freed from particulate material by centrifugation at $2,000 \mathrm{~g}$ for $20 \mathrm{~min}$. The supernatant was stored in lyophilized form and then dissolved again in buffer and freed from fibronectin by three passages over a gelatin-Sepharose column [17]. This preparation contained $5 \mathrm{mg}$ of protein $/ \mathrm{ml}$, with $<2$ $\mu \mathrm{g}$ of fibronectin/ml (as determined with the aforementioned turbidimetric immunoassay).

Preparation of monospecific antibodies to 
fibronectin. Rabbit antibodies to human fibronectin were prepared essentially according to Zardi et al. [18]. Antiserum from immunized rabbits was adsorbed onto insolubilized fibronectin-free plasma proteins [18] and was shown to be monospecific by immunoelectrophoresis. The following immunoglobulin fractions were obtained from the monospecific antiserum by ammonium sulfate precipitation: (I) total immunoglobulins (IgG); (2) immunoglobulins depleted of antifibronectin activity, which were designated $\mathrm{dIgG}$ and were obtained after selective removal of antibodies to fibronectin by affinity chromatography on immobilized fibronectin; and (3) affinity-purified antibodies to fibronectin, which were designated anti-FN IgG and were obtained by elution of the immunoglobulins previously adsorbed on the fibronectin-Sepharose gel. After weakly binding antibodies had been removed with $3 M \mathrm{KSCN}$, affinity-purified anti-FN IgG was eluted from the column with $8 M$ urea.

Modification of $S$. aureus adherence to coverslips. All adherence assays were performed in Dulbecco's PBS solution supplemented with $1 \mathrm{mM}$ $\mathrm{CaCl}_{2}$ and $0.5 \mathrm{mM} \mathrm{MgSO}$ (D-PBS; Gibco, BioCutt, Glasgow, Scotland). When serum, plasma, or albumin from humans or guinea pigs was included in the attachment-phase medium, the protein concentration was adjusted to $5 \mathrm{mg} / \mathrm{ml}$ of D-PBS.

Unimplanted coverslips were treated with protein solutions according to the experimental protocol and were rinsed in PBS before the adherence assay. Unimplanted coverslips were coated with purified fibronectin by incubation for $1 \mathrm{hr}$ at $37 \mathrm{C}$ in a solution containing $125 \mu \mathrm{g}$ of fibronectin $/ \mathrm{ml}$ of PBS and subsequent rinsing in PBS.

Some explanted coverslips were trypsinized before the adherence assay by incubation for $20 \mathrm{~min}$ at $37 \mathrm{C}$ in $1 \mathrm{ml}$ of a solution containing $10 \mu \mathrm{g}$ of purified trypsin/ml (Sigma Chemical, St. Louis). Thereafter, soybean trypsin inhibitor (Sigma) was added to a 10-fold excess concentration, and coverslips were finally rinsed in PBS.

In other experiments fibronectin-coated or explanted coverslips were treated before the adherence assay with one of the three immunoglobulin fractions prepared from antiserum to fibronectin. Both types of coverslips were incubated for $30 \mathrm{~min}$ at $37 \mathrm{C}$ with solutions of immunoglobulins at various concentrations in PBS supplemented with 5 mg of serum albumin/ml (PBS-HSA). Control coverslips, whether coated with fibronectin or explanted, were incubated in parallel in PBS-HSA in the absence of immunoglobulins. Control and immunoglobulin-treated coverslips were rinsed in PBS before being tested in the adherence assay.

Immunofluorescence microscopy. Coverslips freshly explanted from guinea pigs were rinsed and directly incubated for $30 \mathrm{~min}$ at $20 \mathrm{C}$ with $32 \mu \mathrm{g}$ of anti-FN IgG/ml of PBS-HSA. After extensive rinsing in PBS-HSA, coverslips were mounted on glass slides in Eukitt (Gribi, Bern, Switzerland) and were incubated for a further $30 \mathrm{~min}$ with fluorescein-conjugated goat antibody to rabbit IgG (Miles Yeda, Rehovot, Israel) diluted 1:20 in PBS. After extensive rinsing in PBS, coverslips were examined with a microscope (Photomicroscope III ${ }^{\circledR}$; Carl Zeiss Instruments, New York). Photographs were taken with Plus- $X^{\circledR}$ film (Eastman Kodak, Rochester, NY) that was developed at ASA 400 with Diafine ${ }^{\circledR}$ (Eastman Kodak).

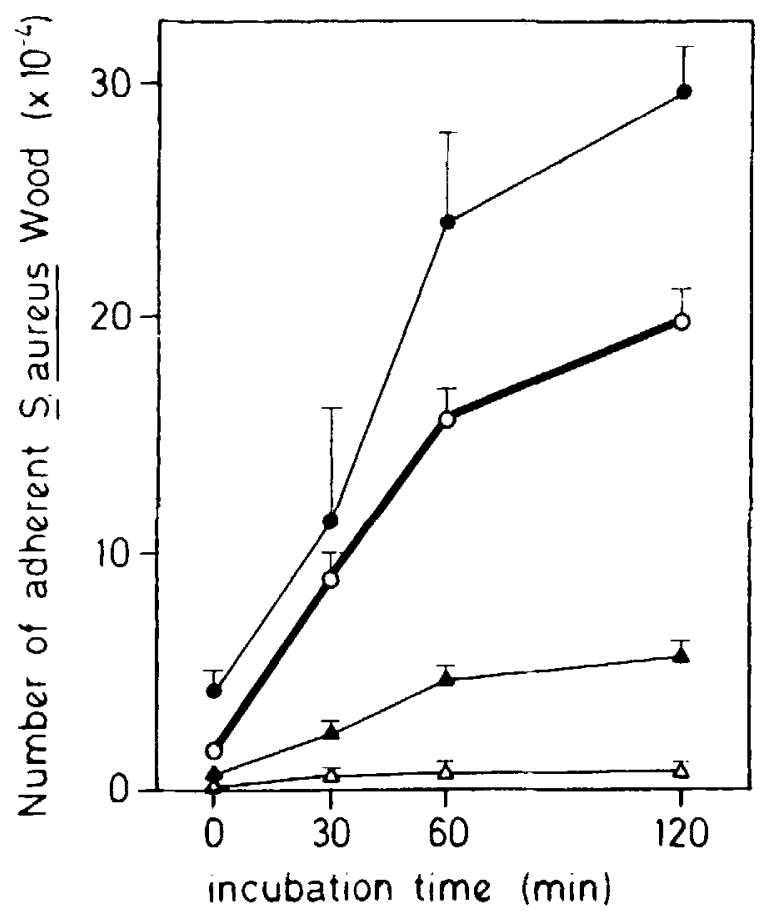

Figure 2. Adherence of $S$. aureus strain Wood 46 to unimplanted MTA coverslips. Concentrations of $10^{5}$ $\mathrm{cfu} / \mathrm{ml}(\triangle), 10^{6} \mathrm{cfu} / \mathrm{ml}(\Delta), 4 \times 10^{6} \mathrm{cfu} / \mathrm{ml}(\mathrm{O})$, and $10^{7}$ $\mathrm{cfu} / \mathrm{ml}(\bullet)$ were incubated with coverslips for periods of $30 \mathrm{sec}$ to $120 \mathrm{~min}$ in $1 \mathrm{ml}$ of D-PBS (attachment phase), and the adherence assay was performed as described in Materials and Methods. The values shown are means ( $\pm \mathrm{SE}$ ) obtained in four experiments. 


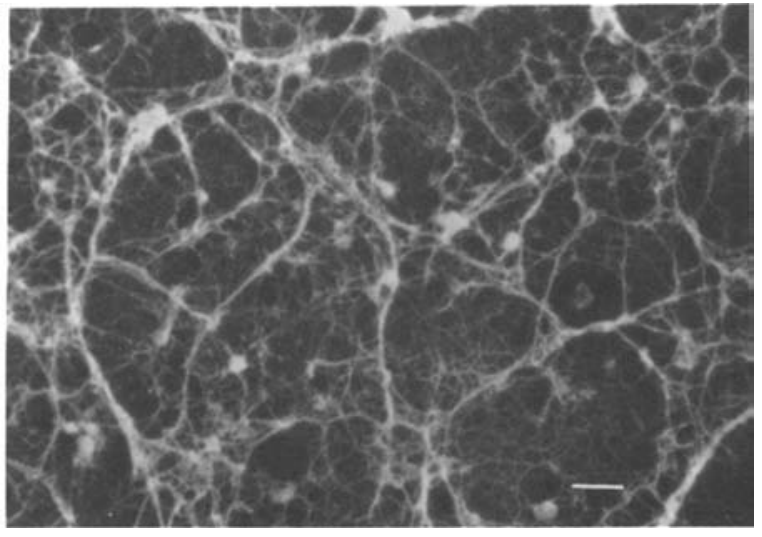

Figure 3. Immunofluorescent staining of explanted MTA coverslips for fibronectin with affinity-purified anti-FN $\operatorname{lgG}(32 \mu \mathrm{g} / \mathrm{ml})$. The staining procedure is detailed in Materials and Methods.

\section{Results}

Figure 2 shows how various incubation periods and bacterial concentrations influenced the adherence of $S$. aureus strain Wood 46 to unimplanted MTA coverslips in D-PBS medium. On the basis of these data, we selected a single bacterial concentration $\left(4 \times 10^{6} \mathrm{cfu} / \mathrm{ml}\right)$ and incubation period $(60$ $\mathrm{min}$ ) for use in all further assays involving unimplanted and explanted coverslips. An increase in coverslip area by a factor of two, three, or four resulted in an increase in the adherence of S. aureus strain Wood 46 by a factor of $2.09 \pm$ $0.08,3.04 \pm 0.19$, or $4.45 \pm 0.34$, respectively (mean $\pm \mathrm{SE}$; three experiments). All further adherence assays were performed with a single coverslip area $(1 \times 1 \mathrm{~cm})$.

The presence of serum proteins at a concentration of $5 \mathrm{mg} / \mathrm{ml}$ had a striking effect on the adherence of $S$. aureus strain Wood 46 to unimplanted coverslips. Table 1 shows that $<10^{3}$ bacteria attached to MTA in the presence of human or guinea pig serum, human plasma, purified human serum albumin, or guinea pig "tissue-cage" fluid [15]. These results represented inhibition of adherence by $>99 \%$ in comparison with adherence to unimplanted coverslips in buffer alone. Lower serum or albumin concentrations also inhibited the adherence of $S$. aureus strain Wood 46, with inhibition by $50 \%$ at a concentration of $0.02 \mathrm{mg}$ of protein $/ \mathrm{ml}$. Preincubation of MTA coverslips with serum, albumin, or tissue-cage fluid at a protein concentration of $\geqslant 0.05 \mathrm{mg} / \mathrm{ml}$, followed by washing in D-PBS, inhibited the adherence of $S$. aureus strain Wood 46 by $90 \%$. Thus, virtually no binding sites for $S$. aureus were left on unimplanted MTA coverslips after exposure to serum, tissue-cage fluid, or albumin.

Explanted coverslips showed modified adherence properties with regard to $S$. aureus strain Wood 46 (table 1). In the presence of human albumin or of serum or tissue-cage fluid from guinea pigs, explanted coverslips bound 15-20 times more bacteria than did unimplanted coverslips ( $P$ $<.001)$. This enhanced adherence to explanted coverslips was reduced by $84 \%$ when the coverslips were pretreated with trypsin.

Microscopic examination revealed that explanted coverslips were coated with fibers and cellular materials that stained intensely with $32 \mu \mathrm{g}$ of anti-FN $\mathrm{IgG} / \mathrm{ml}$ (figure 3); staining was not observed after incubation of coverslips with $\mathrm{dIgG}$ or with preimmune rabbit $\mathrm{IgG}$ at concentrations as high as $500 \mu \mathrm{g} / \mathrm{ml}$ (data not shown). In addition, no staining was observed after incubation with purified fluorescein isothiocyanate-labeled antibody

Table 1. Influence of serum, plasma, interstitial "tissuecage" fluid, purified albumin, and coverslip trypsinization on the adherence of $S$. aureus strain Wood 46 to unimplanted and explanted MTA coverslips.

\begin{tabular}{|c|c|c|}
\hline \multirow{2}{*}{$\begin{array}{l}\text { Treatment of } \\
\text { incubation mixture }\end{array}$} & \multicolumn{2}{|c|}{$\begin{array}{l}\text { No. of staphylococci }\left(\mathrm{cfu} \times 10^{2} \text { ) }\right. \\
\text { adherent to indicated type of coverslip* }\end{array}$} \\
\hline & Unimplanted & Explanted \\
\hline None & $1,590 \pm 110(46)$ & ND \\
\hline Human serum & $4 \pm 2$ & ND \\
\hline Human plasma & $6 \pm 3$ & ND \\
\hline Guinea pig serum & $10 \pm 4$ & $210 \pm 35^{\dagger}$ (4) \\
\hline $\begin{array}{l}\text { Guinea pig tissue- } \\
\text { cage fluid }\end{array}$ & $8 \pm 2$ & $190 \pm 40^{\dagger}(7)$ \\
\hline $\begin{array}{l}\text { Human albumin } \\
\text { Untrypsinized }\end{array}$ & & \\
\hline $\begin{array}{l}\text { coverslips } \\
\text { Trypsinized } \\
\text { coverslips }\end{array}$ & $9 \pm 2$ & $155 \pm 70^{\dagger}(7)$ \\
\hline
\end{tabular}

NOTE. Each adherence assay was performed with a single inoculum of $4 \times 10^{6} \mathrm{cfu}$ of $S$. aureus strain Wood $46 / \mathrm{ml}$ of D-PBS supplemented with the indicated protein sources (protein concentration, $5 \mathrm{mg} / \mathrm{ml}$ ).

* Data are means $\pm \mathrm{SE}$ values, with the number of experiments indicated in parentheses. ND $=$ not done.

$\dagger P<.001$ vs. results obtained with indentically treated, unimplanted coverslips (Student's two-tailed $t$ test).

$\ddagger P<.01$ vs. results obtained with albumin-treated, untrypsinized coverslips (Student's two-tailed $t$ test). 
to fibrinogen at a concentration of $500 \mu \mathrm{g} / \mathrm{ml}$ (Nordic Immunological Laboratory, Tilburg, The Netherlands; data not shown).

To demonstrate that fibronectin deposited on MTA coverslips during in vivo exposure was a major factor mediating the adherence of $S$. aureus strain Wood 46 to the coverslips, we tried to block binding sites with specific antibodies to fibronectin. This approach is feasible with $S$. aureus strain Wood 46, which is devoid of protein A and does not attach nonspecifically to IgG by its Fc portion [16]. Inhibition of the adherence of $S$. aureus strain Wood 46 by antibodies to fibronectin was studied first on unimplanted MTA coverslips coated in vitro with fibronectin. Recent studies by other investigators [23] and by our group [23a] have shown that either fibronectin-coated tissue-culture wells [23] or fibronectin-coated MTA coverslips can promote the adherence of $S$. aureus in the presence of $5 \mathrm{mg}$ of human albumin $/ \mathrm{ml}$ of buffer solution. Under our experimental conditions fibronectincoated coverslips bound $7.72 \times 10^{4} \pm 1.58 \times 10^{4}$ cfu (mean \pm SE; four experiments) of $S$. aureus strain Wood 46 from an initial suspension of $4 \times$ $10^{6} \mathrm{cfu} / \mathrm{ml}$ during incubation for $60 \mathrm{~min}$ at $37 \mathrm{C}$. No adherence $\left(<10^{3} \mathrm{cfu} / \mathrm{ml}\right)$ was observed after either heating of the fibronectin $(5 \mathrm{~min}, 90 \mathrm{C})$ or trypsinization of the fibronectin-coated coverslips (authors' unpublished observations). When fibronectin-coated coverslips were treated with antibodies to fibronectin before the adherence assay, the adherence of $S$. aureus strain Wood 46 was inhibited in a dose-related fashion (figure 4 , graph A). The specificity of this inhibitory effect was shown as follows. First, when antibodies to fibronectin were removed from the immunoglobulin fraction by affinity chromatography on fibronectin-Sepharose, the resulting dIgG did not inhibit the adherence of $S$. aureus (figure 4, graph A). Second, elution of antibody to fibronectin from the fibronectin-Sepharose column led to the recovery of the fraction inhibiting the adherence of $S$. aureus strain Wood 46 (anti-FN IgG), which showed an even higher specific activity (figure 4, graph A.)

When antibodies to fibronectin were added to explanted coverslips, the adherence of $S$. aureus strain Wood 46 was again inhibited in a doserelated manner (figure 4 , graph $B$ ); the degree of inhibition reached $80 \%$ after pretreatment of explanted coverslips with $32 \mu \mathrm{g}$ of anti-FN IgG/ml. The adherence of $S$. aureus strain Wood 46 to ex-

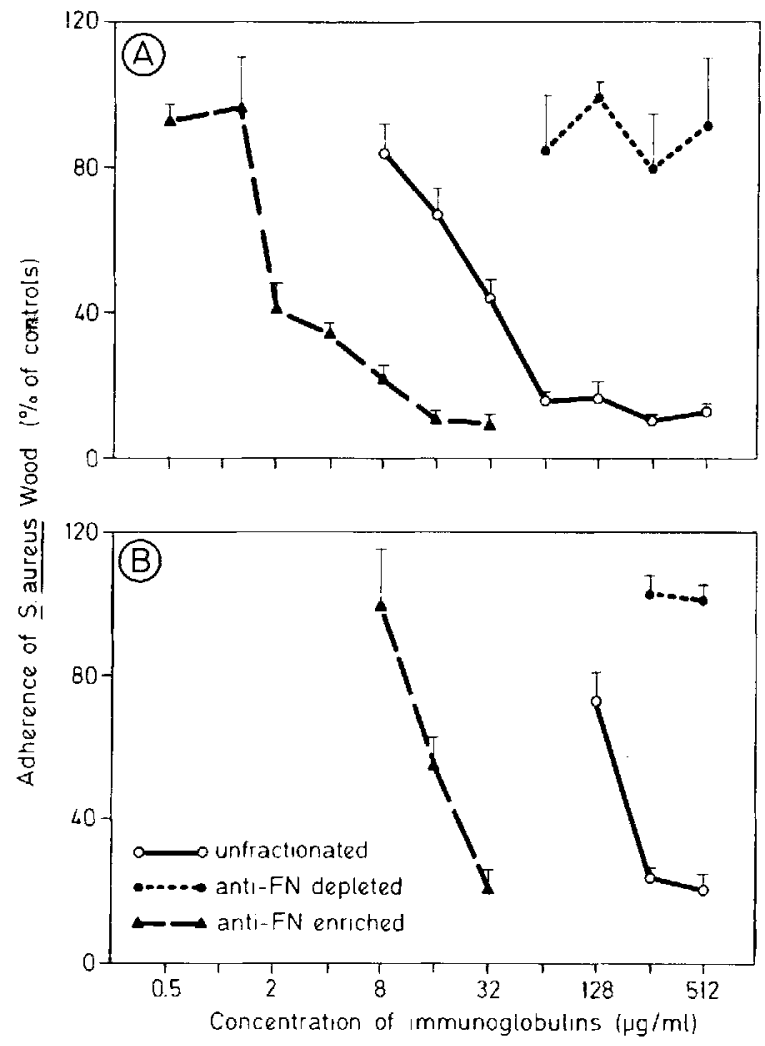

Figure 4. Inhibition of the adherence of $S$, aureus strain Wood 46 to fibronectin-coated, unimplanted MTA coverslips (A) and explanted coverslips (B) by antibodies to fibronectin. Immunoglobulins from sera of rabbits immunized against fibronectin (O), dIgG from the same sera (•), or anti-FN IgG (A) was applied to the coverslips. After rinsing, the adherence assay was performed as described in Materials and Methods in the presence of $5 \mathrm{mg}$ of human serum albumin/ml, which was added to D-PBS during the attachment phase. The values shown are means $( \pm$ SE) obtained in four experiments.

planted coverslips was not inhibited by dIgG (figure 4, graph B). Thus, the fibronectin deposited on MTA coverslips during their implantation into guinea pigs appeared to be a major factor in the binding of $S$. aureus strain Wood 46 to this foreign material.

To exclude the possibility that traces of antibodies to an antigen other than fibronectin were contributing significantly to the inhibition of bacterial adherence, we did the following control experiments. (I) The preparation of anti-FN IgG was further purified of possible antibodies to fibrinogen in undetected trace amounts by chromatography on immobilized purified fibrinogen showing $<0.05 \%$ contamination with fibronectin. After removal of the antibodies to fibrinogen by affinity 
chromatography, anti-FN IgG was still inhibitory to $S$. aureus strain Wood 46 on unimplanted, fibronectin-coated coverslips or on explanted coverslips. Furthermore, the potency of anti-FN IgG was not modified after its incubation with immobilized fibrinogen, since the dose-response curves of the antibody's inhibitory effect on bacterial adherence could be superimposed on those shown in figure 4 (data not shown). (2) Unimplanted MTA coverslips coated with purified fibrinogen (from a solution containing $500 \mu \mathrm{g}$ of protein $/ \mathrm{ml}$ ) were found to bind $S$. aureus strain Wood 46 rather poorly $\left(6 \times 10^{3} \mathrm{cfu}\right)$ in the presence of human albumin in the adherence assay. A similarly low level of adherence was recorded on MTA coverslips precoated with denatured collagen [23a]. (3) Unimplanted MTA coverslips coated with fibrinogen were found to be unaffected by the presence of anti-FN IgG in the adherence assay. (4) The presence of purified fibrinogen $(500 \mu \mathrm{g} / \mathrm{ml})$ in the assay of adherence to fibronectin-coated MTA coverslips was found to have no stimulatory or inhibitory effect on bacterial adherence [23a]. These data made unlikely the contribution of trace amounts of fibrinogen to the process of adherence to fibronectin-coated MTA coverslips.

\section{Discussion}

Fibronectin is a multifunctional glycoprotein found either in connective tissues and basement membranes or in a more soluble form in plasma and other body fluids $[24,25]$. The binding of fibronectin to $S$. aureus has been described in a number of reports [26-28], although the functional significance of this event is still a matter of controversy [29-31]. Our studies suggest that fibronectin may be an important mediator of bacterial adherence and thus may contribute to the pathogenesis of foreign body infection.

A wide array of blood and tissue proteins may interact with either $S$. aureus $[16,23,26-34]$ or implanted synthetic material [11, 12]. Our experimental approach, which involved the use of specific antibodies, allowed us to study the contribution of fibronectin to bacterial adherence under complex conditions that approximated the in vivo situation. Our study was also facilitated by the fact that bacterial adherence to MTA coverslips devoid of adsorbed fibronectin was negligible in albumincontaining media. Vercelloti et al. [23] recently reported similar findings with regard to a different kind of plastic surface: hydrophilic tissue-culture wells.

In a separate study [23a] we defined the experimental conditions that allowed the adsorption of fibronectin onto MTA coverslips. Such adsorption did not occur on the smooth plastic surface in the presence of human serum proteins, as represented by a fibronectin-depleted pool. In contrast, precoating of MTA with denatured collagen resulted in a significant level of adsorption of fibronectin onto MTA coverslips, even in the presence of serum proteins.

In the present study the choice of $S$. aureus strain Wood 46, which is poorly virulent to humans, was motivated by the lack of protein $A$ on the surface of this organism [16]; this characteristic prevents nonspecific binding to the various immunoglobulin fractions used in this study. The fact that this strain can cause infections when associated with a foreign body has been well documented [15]. As far as we know, this is the first report of inhibition of fibronectin-mediated binding of a microorganism by antibodies to fibronectin. A previous attempt to block the binding of fibronectin and a protein A-positive strain of $S$. aureus with $\mathrm{F}\left(\mathrm{ab}^{\prime}\right)_{2}$ fragments of antibodies to fibronectin was unsuccessful [26]. It should be stressed, however, that other fibronectin-mediated functions, such as fibroblast attachment to substrates [35] or fibronectin binding to gelatin [36], can be blocked by antibodies to fibronectin.

At least two types of fibronectin-plasma and cellular [24]--are structurally and functionally similar, although not identical. Monoclonal antibodies have been found that bind preferentially to cellular rather than to plasma fibronectin [24]. MTA coverslips explanted from guinea pigs may contain these different types of fibronectin, and both types may contribute to the adherence of $S$. aureus strain Wood 46, although the relative importance of their contributions remains unknown. Microscopic observation of $S$. aureus strain Wood 46 organisms stained with acridine orange after their attachment to explanted coverslips has shown these organisms to be preferentially located on fibronectin-positive fibers (authors' unpublished observations). That such a fibrillar network may include other macromolecular components (such as collagen and sulfated proteoglycans) codistributed with fibronectin is suggested by other studies of the pericellular matrix of connective tissue [37]. Further studies of the interaction of 
S. aureus strain Wood 46 with fibronectin located on the fibrillar network of explanted coverslips will need to include a consideration of the possible contribution of collagen and proteoglycans to fibronectin-mediated attachment. The authors of recent reports $[23,32,33]$ have stressed the role of tissue-bound fibronectin as an important ligand of $S$. aureus that promotes the development of various types of staphylococcal infections.

Although in the present report we have identified fibronectin as the surface protein involved in the adherence of $S$. aureus to explanted coverslips, the other component of such interations - namely, the bacterial adhesin-has yet to be defined for staphylococcal strain Wood 46. We found no difference in bacterial adherence to explanted coverslips when $S$. aureus strain Wood 46 was incubated with liquids varying in their protein composition, such as serum, interstitial fluid, or purified albumin (table 1). Such data do not exclude the possibility that other purified blood fractions interacting mainly with the bacterial surface may modulate the subsequent adherence of $S$. aureus to explanted coverslips. The possible interference of soluble fibronectin with the adherence of $S$. aureus to surface-bound fibronectin was recently considered [23]. Surprisingly, S. aureus pretreated with purified soluble fibronectin showed an enhanced ability to adhere to the fibronectin of endothelial cells [23]. These data may be the result of bacterial clumping induced by fibronectin or may reflect other, more complex processes.

In conclusion, our studies have demonstrated that fibronectin is deposited on the surface of a foreign body implanted in an animal. This deposited fibronectin plays an important role in the attachment of $S$. aureus strain Wood 46 to the foreign material. It remains to be established whether our observation is restricted to the type of material studied and the experimental system selected or whether it applies to other types of prosthetic devices, including those widely used in various clinical situations.

\section{References}

1. Wilson PD, Salvati EA, Aglietti LJ, Kutner LJ. The problem of infection in endoprosthetic surgery of the hip joint. Clin Orthop 1973;96:213-21

2. Fitzgerald RH Jr, Peterson LFA, Washington JA II, Van Scoy RE, Coventry MB. Bacterial colonization of wounds and sepsis in total hip arthroplasty. $\mathrm{J}$ Bone Joint Surg 1973;55:1242-50

3. Kloster FE. Complications of artificial heart valves. JAMA 1979;241:2201-3

4. Maki DG. Infections associated with intravascular lines. In: Remington JS, Swartz MN, eds. Current clinical topics in infectious diseases. Vol 3. New York: McGraw-Hill, 1980:309-63

5. Elek SD, Conon PE. The virulence of Staphylococcus pyogenes for man: a study of the problems of wound infection. Br J Exp Pathol 1957;38:573-86

6. James RC, MacLeod CJ. Induction of staphylococcal infections in mice with small inocula introduced on sutures. Br J Exp Pathol 1961;42:266-77

7. Noble WC. The production of subcutaneous staphyloccal skin lesions in mice. Br J Exp Pathol 1965; 46:254-62

8. Costerton JW, Geesey GG, Cheng K-J. How bacteria stick. Sci Am 1978;238:86-96

9. Peters G, Locci R, Pulverer G. Microbial colonization of prosthetic devices. II. Scanning electron microscopy of naturally infected intravenous catheters. Zentralbl Bakteriol [B] 1981;173:293-9

10. Christensen GD, Simpson WA, Bisno AL, Beachey EH. Adherence of slime-producing strains of Staphylococcus epidermidis to smooth surfaces. Infect Immun 1982;37:318-26

11. Baier RE. The organization of blood components near interfaces. Ann NY Acad Sci 1977;283:17-36

12. Cottonaro CN, Rookh HV, Shimizu G, Sperling DR. Quantitation and characterization of competitive protein binding to polymers. Trans Am Soc Artif Intern Organs 1981;27:391-5

13. Fletcher $M$. The effects of proteins on bacterial attachment to polystyrene. J Gen Microbiol 1976;94:400-4

14. Stinson MW, Jinks DC, Merrick JM. Adherence of Streptococcus mutans and Streptococcus sanguis to salivary components bound to glass. Infect Immun 1981;32: 583-91

15. Zimmerli W, Waldvogel FA, Vaudaux $P$, Nydegger UE. Pathogenesis of foreign body infection: description and characteristics of an animal model. $J$ Infect Dis 1982;146:487-97

16. Kronvall G, Quie PG, Williams RC Jr. Quantitation of staphylococcal protein A: determination of equilibrium constant and number of protein $A$ residues on bacteria. J Immunol 1970;104:273-8

17. Engvall E, Ruoslahti E. Binding of soluble form of fibroblast surface protein, fibronectin, to collagen. Int J Cancer 1977;20:1-5

18. Zardi L, Siri A, Carnemolla B, Cosulich E, Viale G, Santi L. A simplified procedure for the preparation of antibodies to serum fibronectin. J Immunol Methods 1980;34:155-65

19. Morgenthaler JJ. Hydrophobic chromatography of fibronectin. FEBS Let 1982;150:81-4

20. Laemmli UK. Cleavage of structural proteins during the assembly of the head of bacteriophage T4. Nature 1970;227:680-5

21. Mosher DF. Fibronectin. Prog Hemost Thromb 1980; 5:111-51 
22. Doran JA, Mansberger AR, Reese AC. Cold insoluble globulin-enhanced phagocytosis of gelatinized targets by macrophage monolayers: a model system. J Reticuloendothel Soc 1980;27:471-83

23. Vercelloti GM, Lussenhop D, Peterson PK, Furcht LT, McCarthy JB, Jacob HS, Moldow CF. Bacterial adherence to fibronectin and endothelial cells: a possible mechanism for bacterial tissue tropism. J Lab Clin Med 1984;103:34-43

23a. Vaudaux P, Waldvogel FA Jr, Morgenthaler JJ, Nydegger UE. Adsorption of fibronectin onto polymethylmethacrylate and its promoting effect on Staphylococcus aureus adherence. Infect Immun, 1984 (in press)

24. Hynes RO, Yamada KM. Fibronectins: multifunctional modular glycoproteins. J Cell Biol 1982;95:369-77

25. Mosesson MW, Amrani DL. The structure and biologic activities of plasma fibronectin. Blood 1980;56:145-58

26. Kuusela P. Fibronectin binds to Staphylococcus aureus. Nature 1978;276:718-20

27. Mosher DF, Proctor RA. Binding and factor XIII-mediated cross-linking of a 27-kilodalton fragment of fibronectin to Staphylococcus aureus. Science 1980;209:927-9

28. Rydén C, Rubin K, Speziale P, Höök M, Lindberg M, Wadström T. Fibronectin receptors from Staphylococcus aureus. J Biol Chem 1983;258:3396-401

29. Lanser ME, Saba TM. Fibronectin as a co-factor necessary for optimal granulocyte phagocytosis of Staphylococcus aureus. J Reticuloendothel Soc 1981;30:415-24

30. Verbrugh HA, Peterson PK, Smith DE, Nguyen B-YT, Hoidal JR, Wilkinson BJ, Verhoeff J, Furch LT. Human fibronectin binding to staphylococcal surface protein and its relative inefficiency in promoting phagocytosis by human polymorphonuclear leukocytes, monocytes, and alveolar macrophages. Infect Immun 1981;33:811-9

31. Van de Water L, Destree AT, Hynes RO. Fibronectin binds to some bacteria but does not promote their uptake by phagocytic cells. Science 1983;220:201-4

32. Proctor RA, Mosher DF, Olbrantz PJ. Fibronectin binding to Staphylococcus aureus. J Biol Chem 1982;257: 14788-94

33. Proctor RA, Hamill RJ, Mosher DF, Textor JA, Olbrantz PJ. Effects of subinhibitory concentrations of antibiotics on Staphylococcus aureus interactions with fibronectin. J Antimicrob Chemother 1983;12(Suppl C):85-95

34. Davison VE, Sanford BA. Factors influencing adherence of Staphylococcus aureus to influenza A virus-infected cell cultures. Infect Immun 1982;37:946-55

35. Pierschbacher MD, Hayman EG, Ruoslahti E. Location of the cell-attachment site in fibronectin with monoclonal antibodies and proteolytic fragments of the molecule. Cell 1981;26:259-67.

36. McDonald JA, Broekelmann TJ, Kellay DG, Villiger B. Gelatin-binding domain-specific anti-human plasma fibronectin Fab' $^{\prime}$ inhibits fibronectin-mediated gelatin binding but not cell spreading. $J$ Biol Chem 1981;256:5583-7

37. Hedman K, Johannson S, Vartio T, Kjellén L, Vaheri A, Höök M. Structure of the pericellular matrix: association of heparan and chondroitin sulfates with fibronectin-procollagen fibers. Cell 1982;28:663-71 